\title{
ORGANIC BY-PRODUCTS OF DRINKING WATER CHLORINATION
}

\section{A. D. NIKOLAOU* \\ M. N. KOSTOPOULOU \\ T. D. LEKKAS}

\author{
Department of Environmental Studies. \\ University of the Aegean \\ Karadoni 17, 81100 Mytilene, Greece
}

\section{ABSTRACT}

Chlorination of drinking water leads to the formation of a variety of Disinfection By-Products (DBPs) that may have adverse health effects on humans. Research on this subject has been continued and new epidemiological and toxicological studies have been conducted. This review summarizes factors affecting DBP formation and predictive equations proposed for it, physical and chemical properties, environmental fate, actual measurements of these compounds and technologies for controlling them, as well as regulation and currently proposed changes of their Maximum Contaminant Levels (MCLs) after evaluation by EPA of new data available.

KEYWORDS: Disinfection by-products, Chlorination, Trihalomethanes, Haloacetic acids

\section{INTRODUCTION}

The reaction of chlorine with Natural Organic Materials (NOM) existing in surface water leads to the formation of halogenated Disinfection ByProducts (DBPs) (Stevens et al., 1976; Babcock and Singer, 1979; Christman et al., 1983) including trihalomethanes, haloacetic acids, haloaldehydes, haloketones, haloacetonitriles, chloropicrin, chlorophenols.

Trihalomethanes (THMs) were the first category of DBPs to be detected in drinking water (Bellar et al., 1974; Rook, 1974), followed by haloacetic acids (Quimby et al., 1980; Christman et al., 1983; Miller and Uden, 1983; Reckow and Singer, 1984; Krasner et al., 1989) and haloacetonitriles, haloketones, chloropicrin at lower concentrations (Trehy and Bieber, 1980; Barry, 1983; Krasner et al., 1989; Williams et al., 1997). According to animal studies, dichloroacetic acid is believed to be a more potent carcinogen than THMs (Bull and Kopfler, 1991; Regli et al., 1992). Dichloroacetonitrile has been shown to be mutagenic in bacterial assays (Simmon et al., 1977). 
These observations resulted in an increasing number of studies and regulations, in an attempt to reduce the health risk deriving from exposure to DBPs and simultaneously keep the risk of microbial disease at as low levels as possible. This review summarizes information including formation, properties, actual measurements and regulation of DBPs.

\section{FACTORS AFFECTING DBP FORMATION - PROPOSED PREDICTIVE EQUATIONS}

The main factors affecting DBP formation (Singer, 1993; Singer, 1994; Pourmoghaddas and Stevens, 1995; Lekkas, 1996) are $\mathrm{pH}$, contact time, temperature and season, concentration and properties of Natural Organic Materials (NOM), concentration of chlorine and residual chlorine and concentration of bromide.

pH. With increasing $\mathrm{pH}$, trihalomethane formation increases, whereas haloacetic acid formation decreases (Krasner et al., 1989; Pourmoghaddas and Stevens, 1995). At high $\mathrm{pH}$ values, hydrolysis of many halogenated DBPs occurs (Krasner et al., 1989). As a result, total organic halide (TOX) concentration is lower at $\mathrm{pH}>8$ (Singer, 1994).

Contact time. With increasing contact time, trihalomethane and haloacetic acid formation increases. On the other hand, DBPs such as haloacetonitriles and haloketones, which were initially formed, decay as a result of hydrolysis and reactions with residual chlorine (Singer, 1994).

Temperature and season. When temperature increases, reactions are faster and a higher chlorine dose is required, leading to higher formation of DBPs. Subsequently, DBP concentrations are expected to be higher in summer than in winter (Williams et al., 1997; Golfinopoulos et al., 1993; Golfinopoulos et al., 1996a,b; LeBel et al., 1997). However, influence of season and weather on the nature of NOM and on bromide concentration must be taken into account.

Concentration and properties of NOM. With increasing NOM concentration, DBP formation increases. Properties of NOM play an important role as well, since activated aromatic content of NOM increases DBP formation (Reckow et al., 1990). In addition, NOM contains hydrophobic and hydrophilic materials, the nature and distribution of which may vary with different types of vegetation in the watershed and different species of algae in water. This results in varying influence of NOM on DBP formation (Singer, 1994).

Concentration of chlorine and residal chlorime With increasing chlorine dose and residual, formation of haloacetic acids becomes greater than trihalomethane formation. Also, more trihalogenated than mono- and di-halogenated species and more chlorinated than brominated species are formed (Singer, 1994). Depletion of the free chlorine residual ceases THM and haloacetic acid formation. However, limited formation of some other DBPs continues due to hydrolysis reactions (Singer, 1994).

conoentration of bromide. In the presence of bromide ion (Br-), more brominated and mixed chloro-bromo derivatives are formed (Krasner et al., 1989; Peters et al., 1991; Heller-Grossman et al., 1993; Pourmoghaddas and Stevens, 1995). This is the result of bromide oxidation to hypobromous acid $(\mathrm{HOBr})$ by chlorine and the reaction of $\mathrm{HOBr}$ and residual $\mathrm{HOCl}$ with NOM. In waters with very high bromide concentration, the brominated species -bromoform, dibromoacetic acidmay be the major species formed (Singer, 1994).

Some predictive equations for the formation of DBPs based on the previous factors are give below.

$$
C_{\text {TTHM }}=0.00309\left(T O C \cdot U V_{254}\right)^{0.440} C_{C l_{2}}^{0.409} t^{0.265} T^{1.06}
$$

$(p H-2.6)^{0.715}\left(C_{B r}+1\right)^{0.03}$

(Harrington et al., 1992)

$$
\begin{aligned}
& C_{\text {TTHM }}=52.13+10.73 \ln \left(C_{c h l a}\right)-20.95 \mathrm{pH}+ \\
& +243.23 C_{B r}-147.45 C_{B r}^{2}-27.77 \mathrm{~S}+ \\
& +120.01 S p-7.37 T \cdot S p+1.52 T C_{C l_{2}} \\
& \text { (Golfinopoulos et al., 1998) }
\end{aligned}
$$

THMFP $=10+17 A c t_{A r-R}$

(Rechow et al., 1990)

$$
\begin{aligned}
& C_{\mathrm{CHCl}_{3}}=0 / 278\left(\text { TOC } \cdot U V_{254}\right)^{0.616} C_{\mathrm{Cl}_{2}}^{0.391} t^{0.265} T^{1.15} \\
& (p H-2.6)^{0.800}\left(C_{B r}+1\right)^{-2.23}
\end{aligned}
$$


$C_{\mathrm{HCl}_{3}}=k_{1} k_{2} \mathrm{TOC}^{0.95}\left(\frac{C_{\mathrm{Cl}_{2}}}{\mathrm{TOC}}\right)^{0.28} t^{z}$

(Engerholm and Amy, 1983)

$C_{\mathrm{CHBrCl}_{2}}=0.863\left(\mathrm{TOC} \cdot U V_{254}\right)^{0.177} C_{\mathrm{Cl}_{2}}^{0.309} t^{0.271} T^{0.720}$

$(p H-2.6)^{0.925}\left(C_{B r}+1\right)^{0.722}$

(Malcolm Pirnie Inc., 1992)

$C_{\mathrm{CHBr}_{2} \mathrm{Cl}}=2.57\left(\frac{U V_{254}}{\mathrm{TOC}}\right)^{-0.184} \mathrm{C}_{\mathrm{Cl}_{2}}^{-0.0746} t^{0.252} T^{0.57}$

$(p H-2.6)^{1.35} C_{B r}^{2.08}$

(Malcolm Pirnie Inc., 1992)

$D_{D C A A}=0.605 T O C^{0.291} U V_{254}^{0.726} C_{C l_{2}}^{0.480} t^{0.239} T^{0.665}$

$\left(C_{B r}+1\right)^{-0.568}$

(Malcolm Pirnie Inc., 1992)

$C_{T C A A}=87.102$ TOC $^{0.335} U V_{254}^{0.901} C_{C_{2}}^{0.881} t^{0.264} p^{-1.732}$

$\left(C_{B r}+1\right)^{-0.679}$

(Malcolm Pirnie Inc., 1992)

$\frac{T C A A F P}{T T H M F P}=0.6+14 U V_{254}$

(Reckow et al., 1990)
$D C A N F P=-2.3+0.053 \mathrm{C}_{\text {Org- } N}$

(Reckow et al., 1990)

The applicability of equations (1), (4), (6), (7), (8) and (9) has not been tested in waters with relatively high bromide concentrations, where the distribution of the species formed will probably be different. Additionally, high ammonia concentration also may affect DBP formation, due to consumption of chlorine (Harrington et al., 1992). Finally, season influence has not been taken into account, although it may have a significant effect on DBP formation. Season alinfluences has been incorporated into equation (2), which however does not include contact time (Golfinopoulos et al., 1998). For equation (5), the limitation is that only one type of humic acid has been considered as DBP precursor, which is not true for natural waters (Engerholm and Amy, 1983). Further investigation of the influence of natural organic materials is necessary in order to improve the applicability of the above equations for predicting DBP formation.

Comparison of Malcolm Pirnie Inc. predictions by the numerical models shown above and measured concentrations in California and North Carolina drinking waters (Greiner et al., 1992) has shown similar percentage deviations and central tendencies. The same is true for the comparison of Golfinopoulos et al., model predictions and measured concentrations in Athens drinking water (Golfinopoulos et al., 1998).

\section{CATEGORIES AND MEASUREMENTS OF DBPS}

In order to minimize DBP formation, it is necessary to study and analyze their occurrence and

Table 1. Values of constants in predictive equation for chloroform formation (Engerholm and Amy, 1983)

\begin{tabular}{|c|c|c|c|}
\hline Constant & $\mathrm{pH}$ Value & Temperature $\left({ }^{\circ} \mathrm{C}\right)$ & Value of constant \\
\hline $\mathrm{x}$ & All & All & 0.95 \\
$\mathrm{y}$ & All & All & 0.28 \\
$\mathrm{z}$ & & 10 & 0.19 \\
& & 20 & 0.22 \\
& & 35 & 0.28 \\
$\mathrm{k}_{1}$ & 5.5 & & 0.82 \\
& 7.0 & & 1.00 \\
& 8.5 & 10 & 1.22 \\
$\mathrm{k}_{2}$ & & 20 & 13.59 \\
& & 35 & 16.75 \\
& & & 23.35 \\
\hline
\end{tabular}


behaviour in water. Concentrations of compounds belonging to different categories of DBPs have been measured in several countries. Results of such measurements are presented in this section. Health effects are also mentioned. Physical chemical properties and environmental fate of DBPs need to be taken into account as well and are summarized in Annex I (Sittig, 1985; Ehrenfeld et al., 1986; Merck, 1989; Vogel, 1989; Howard 1991a,b; Mackay et al., 1992a,b; Lyde, 1993-94; Shiu et al., 1994; Bowden et al., 1998).

\section{A. Trihalamethanes}

This category includes the following substances: Bromodichloromethane $\left(\mathrm{CHBrCl}_{2}\right)$, Bromoform $\left(\mathrm{CHBr}_{3}\right)$, Chloroform $\left(\mathrm{CHCl}_{3}\right)$ and Dibromochloromethane $\left(\mathrm{CHBr}_{2} \mathrm{Cl}\right)$.

Additional lifetime cancer risk is $1 / 100000$ at a concentration of $1.9 \mu \mathrm{g} / \mathrm{l}$ for bromodichloromethane, bromoform and chloroform. According to EPA, these three substances belong to carcinogens and Priority Toxic Pollutants. Bromoform, chloroform and dibromochloromethane belong to the category of Hazardous Wastes. Dibromochloromethane has shown positive results for mutagenesis in Salmonella typhimurium.

Measurements of THM concentrations in drinking waters are given in Table 2.

\section{B. Hloactic acids}

The DBPs belonging to this category are Bromoacetic acid (MBA) $\left(\mathrm{BrCH}_{2} \mathrm{COOH}\right)$,
Bromochloroacetic acid (BCA) (BrClCHCOOH), $\alpha-, \beta$ - and $\gamma$-Chloroacetic acid (MCA) $(\mathrm{ClCH} 2 \mathrm{COOH})$, dibromoacetic acid (DBA) $\left(\mathrm{Br}_{2} \mathrm{CHCOOH}\right)$, dibromochloroacetic acid (DBCA) $\left(\mathrm{Br}_{2} \mathrm{ClCCOOH}\right)$, dichloroacetic acid (DCA) $\left(\mathrm{Cl}_{2} \mathrm{CHCOOH}\right)$, dichlorobromoacetic acid (DCBA) $\left(\mathrm{Cl}_{2} \mathrm{BrCCOOH}\right)$, tribromoacetic acid (TBA) $\left(\mathrm{Br}_{3} \mathrm{CCOOH}\right)$ and trichloroacetic acid (TCA) $\left(\mathrm{Cl}_{3} \mathrm{CCOOH}\right)$.

Monochloroacetic acid attacks skin, eyes and respiratory system. Dichloroacetic acid and trichloroacetic acid are animal carcinogens (Bull and Kopfler, 1991; Regli et al., 1992).

Measurements of haloacetic acid concentrations in drinking waters are given in Table 3.

\section{Haloaldehycles}

Bromoacetaldehyde $\left(\mathrm{BrCH}_{2} \mathrm{CHO}\right)$, chloroacetaldehyde $\left(\mathrm{ClCH}_{2} \mathrm{CHO}\right)$, dibromoacetaldehyde $\left(\mathrm{Br}_{2} \mathrm{CHCHO}\right)$, dichloroacetaldehyde $\left(\mathrm{Cl}_{2} \mathrm{CHCHO}\right)$, tribromoacetaldehyde $\left(\mathrm{Br}_{3} \mathrm{CCHO}\right)$, trichloroacetaldehyde $\left(\mathrm{Cl}_{3} \mathrm{CCHO}\right)$ and chloral hydrate $\left(\mathrm{C}_{2} \mathrm{H}_{3} \mathrm{Cl}_{3} \mathrm{O}_{2}\right)$ are the main members of this category of DBPs.

Chloroacetaldehyde attacks eyes, skin and mucous membranes. According to EPA, chloral hydrate belongs to possible human carcinogens.

Measurements of chloral hydrate concentrations in drinking waters are given in Table 4.

\section{Haloketones}

1,1-dichloroacetone $\left(\mathrm{C}_{2} \mathrm{H}_{4} \mathrm{Cl}_{2} \mathrm{CO}\right)$, 1,3-di-

Table 2. Measured concentrations of THMs in chlorinated drinking water

\begin{tabular}{ccccc}
\hline & $\mathrm{CHCl}_{3}\left(\mu \mathrm{g} \mathrm{l}^{-1}\right)$ & $\mathrm{CHCl}_{2} \mathrm{Br}\left(\mu \mathrm{g} \mathrm{l}^{-1}\right)$ & $\mathrm{CHClBr}_{2}\left(\mu \mathrm{g} \mathrm{l}^{-1}\right)$ & $\mathrm{CHBr}_{3}\left(\mu \mathrm{g} \mathrm{l}^{-1}\right)$ \\
\hline \multicolumn{2}{l}{ United States (Krasner et al., 1989$)$} & & & \\
Spring & 15 & 6.9 & 2.6 & 0.33 \\
Summer & 15 & 10 & 4.5 & 0.57 \\
Fall & 13 & 5.5 & 3.8 & 0.88 \\
Winter & 9.6 & 4.1 & 2.7 & 0.51 \\
Israel (Heller-Grossman et al., 1993$)$ & & & \\
Summer & 10.5 & 39 & 203 & 353 \\
Winter & 20 & 25.5 & 196 & 265 \\
Greece (Golfinopoulos et al., 1993$)$ & 7.0 & 7.0 & & \\
Spring & 7.0 & 5.0 & 9.0 & 7.0 \\
Summer & $2-11$ & $3-24$ & 5.0 & 4.0 \\
Range (yearly) & & $6-30$ & $4-50$ \\
Canada (LeBel et al., 1997) & 38.5 & 4.2 & & \\
\hline Yearly mean & $10.7-92.1$ & $2.3-6.7$ & $<0.1-0.5$ & $<0.1-0.3$ \\
Range & & &
\end{tabular}


Table 3. Measured concentrations of haloacetic acids in chlorinated drinking water

\begin{tabular}{|c|c|c|c|c|c|c|c|c|c|}
\hline$\left(\mu \mathrm{gl}^{-1}\right)$ & $\begin{array}{l}\text { MCA } \\
\left(\mu \mathrm{gl}^{-1}\right)\end{array}$ & $\begin{array}{c}\text { DCA } \\
\left(\mu \mathrm{g} \mathrm{l}^{-1}\right)\end{array}$ & $\begin{array}{c}\text { MBA } \\
\left(\mu \mathrm{gl}^{-1}\right)\end{array}$ & $\begin{array}{c}\text { BCA } \\
\left(\mu \mathrm{gl}^{-1}\right)\end{array}$ & $\begin{array}{c}\text { TCA } \\
\left(\mu \mathrm{g} \mathrm{l}^{-1}\right)\end{array}$ & $\begin{array}{c}\text { DBA } \\
\left(\mu \mathrm{g} \mathrm{l}^{-1}\right)\end{array}$ & $\begin{array}{l}\text { BDCA } \\
\left(\mu \mathrm{gl}^{-1}\right)\end{array}$ & $\begin{array}{l}\text { CDBA } \\
\left(\mu \mathrm{gl}^{-1}\right)\end{array}$ & $\begin{array}{c}\text { TBA } \\
\left(\mu \mathrm{g} \mathrm{l}^{-1}\right)\end{array}$ \\
\hline \multicolumn{10}{|c|}{ United States (Krasner et al., 1989) } \\
\hline Spring & $<1.0$ & 7.3 & $<0.5$ & NM & 5.8 & 0.9 & NM & NM & NM \\
\hline Summer & 1.2 & 6.8 & $<0.5$ & NM & 5.8 & 1.5 & NM & NM & NM \\
\hline Fall & $<1.0$ & 6.4 & $<0.5$ & NM & 6.0 & 1.4 & NM & NM & NM \\
\hline Winter & 1.2 & 5.0 & $<0.5$ & NM & 4.0 & 1.0 & NM & NM & NM \\
\hline \multicolumn{10}{|c|}{ Israel (Heller-Grossman et al., 1993) } \\
\hline Summer & NM & 12 & NM & 36 & 6 & 90 & NM & 90 & 80 \\
\hline Winter & NM & 18 & NM & 29 & 5 & 69 & NM & 90 & 50 \\
\hline \multicolumn{10}{|c|}{ The Netherlands (Peters et al., 1991) } \\
\hline Range & NM & $0.2-3$ & $0.1-0.5$ & $0.1-2.5$ & $0.1-1.4$ & $0.1-6.5$ & $0.1-1.7$ & $0.2-1.6$ & $0.3-2.1$ \\
\hline \multicolumn{10}{|c|}{ Canada (LeBel et al., 1997) } \\
\hline Yearly mean & 1.5 & 12.7 & $<0.01$ & NM & 12.7 & $<0.01$ & NM & NM & NM \\
\hline Range & $0.2-7.8$ & $2.1-26.2$ & $<0.01$ & NM & $1.7-36.8$ & $<0.01$ & NM & NM & NM \\
\hline
\end{tabular}

$\mathrm{NM}=$ not measured

chloroacetone $\left(\mathrm{C}_{2} \mathrm{H}_{4} \mathrm{Cl}_{2} \mathrm{CO}\right)$ and 1,1,1-trichloroacetone $\left(\mathrm{C}_{2} \mathrm{H}_{3} \mathrm{Cl}_{3} \mathrm{CO}\right)$ are the haloketones identified in water as by-products of chlorination.

Carcinogenic and mutagenic effects of the haloketones 1,1 - dichloropropanone and 1,1,1 trichloropropanone on mice have been reported (Bull \& Robinson, 1986).

Measurements of haloketone concentrations in drinking waters are given in Table 5.

\section{E. Hloactonitriles}

The substances included in the present category are bromoacetonitrile (BAN) $\left(\mathrm{BrCH}_{2} \mathrm{CN}\right)$, bromochloroacetonitrile (BCAN) ( $\mathrm{BrClCHCN})$, chloroacetonitrile (CAN) $\left(\mathrm{ClCH}_{2} \mathrm{CN}\right)$, dibromoacetonitrile (DBAN) $\left(\mathrm{Br}_{2} \mathrm{CHCN}\right)$,

dichloroacetonitrile (DCAN) $\left(\mathrm{Cl}_{2} \mathrm{CHCN}\right)$, tribromoacetonitrile (TBAN) $\left(\mathrm{Br}_{3} \mathrm{CCN}\right)$ and trichloroacetonitrile (TCAN) $\left(\mathrm{Cl}_{3} \mathrm{CCN}\right)$.

Dichloroacetonitrile has been shown to be mutagenic in bacterial assays (Simmon et al., 1977). Trichloroacetonitrile attacks eyes and skin. Carcinogenic and mutagenic effects of the haloacetonitriles BAN, DBAN and BCAN on mice have been reported (Bull \& Robinson, 1986). Haloacetonitriles have also been found to damage DNA of mice (Pereira et al., 1986).

Measurements of haloacetonitrile concentrations in drinking waters are given in Table 6 .

\section{F. Chlorqpicrin: $\mathrm{CCl}_{3} \mathrm{NO}_{2}$}

Chloropicrin attacks respiratory system, lungs, eyes and skin.

Measurements of chloropicrin concentrations in drinking waters are given in Table 7.

\section{G. Chlorophenols}

This category includes 2-, 3- and 4-chlorophenol $\left(\mathrm{ClC}_{6} \mathrm{H}_{4} \mathrm{OH}\right), 2,3-$, 2,4- , 2,5- , 2,6- , 3,4- and 3,5- dichlorophenol $\left(\mathrm{Cl}_{2} \mathrm{C}_{6} \mathrm{H}_{3} \mathrm{OH}\right), 2,3,4-$, 2,3,5-,

Table 4. Measured concentrations of chloral hydrate in chlorinated drinking water

\begin{tabular}{cc}
\hline & Chloral hydrate $\left(\mu \mathrm{g} \mathrm{l}^{-1}\right)$ \\
\hline United States (Krasner et al., 1989) & 1.8 \\
Spring & 3.0 \\
Summer & 2.2 \\
Fall & 1.7 \\
Winter & \\
Canada (LeBel et al., 1997) & 3.4 \\
Yearly mean & $0.6-10.5$ \\
Range &
\end{tabular}


Table 5. Measured concentrations of haloketones in chlorinated drinking water

\begin{tabular}{ccc}
\hline & 1,1- Dichloroacetone $\left(\mu \mathrm{g} \mathrm{l}^{-1}\right)$ & $1,1,1$ - Trichloroacetone $\left(\mu \mathrm{g} \mathrm{l}^{-1}\right)$ \\
\hline United States (Krasner et al., 1989) & & \\
Spring & 0.52 & 0.80 \\
Summer & 0.46 & 0.35 \\
Fall & 0.52 & 0.60 \\
Winter & 0.55 & 0.66 \\
Canada (LeBel et al., 1997) & & \\
Yearly mean & 0.7 & 2.4 \\
Range & $0.4-1.3$ & $<0.1-5.7$ \\
\hline
\end{tabular}

2,3,6- , 2,4,5- , 2,4,6- and 3,4,5- trichlorophenol $\left(\mathrm{Cl}_{3} \mathrm{C}_{6} \mathrm{H}_{2} \mathrm{OH}\right)$ and pentachlorophenol $\left(\mathrm{Cl}_{5} \mathrm{C}_{6} \mathrm{OH}\right)$. According to EPA, 2-chlorophenol, 2,4dichlorophenol and 2,4,6-trichlorophenol belong to Priority Toxic Pollutants and Hazardous Wastes. Additional lifetime cancer risk is $1 / 100000$ at a concentration of $12 \mu \mathrm{g} \mathrm{l}^{-1}$.

Measurements of chlorophenol concentrations in drinking waters are given in Table 8.

\section{REGULATION OF DISINFECTION BY-PRODUCTS}

In November 1979, USEPA set a Maximum Contaminant Level (MCL) for total THMs of $0.100 \mathrm{mg} \mathrm{l}^{-1}$ as an annual average (USEPA, 1979). In November 1992, a Regulatory Negotiation Process started in order to ensure the microbiological safety of drinking water and simultaneously reduce the risk deriving from exposure to disinfectants and DBPs. For this goal to be achieved, a large amount of necessary information was not available. Nevertheless, the negotiations resulted in the Disinfectants/DBPs Stage 1 rule proposed by USEPA in 1994. According to this rule (USEPA, 1998a):

- the MCL for total THMs was lowered from 0.100 to $0.080 \mathrm{mg} \mathrm{l}^{-1}$
- a MCL of $0.060 \mathrm{mg} \mathrm{l}^{-1}$ for the sum of concentrations of five haloacetic acids (monochloro-, dichloro-, trichloro-, monobromoand dibromo-acetic acid) was added.

Epidemiological studies published after the 1994 proposed rule were evaluated by EPA (McGeehin et al., 1993; Vena et al., 1993; King et al., 1996; Doyle et al., 1997; Freedman et al., 1997; Cantor et al., 1998; Hildesheim et al., 1998). Better evidence for an association between exporure to chlorinated water and cancer derives from bladder cancer studies than from colon and rectal cancer studies (USEPA, 1998b). EPA estimates that an upper bound range of 1100-9300 potential bladder cancer cases per year could be associated with exposure to DBPs in chlorinated surface water (USEPA, 1998a). Several studies of association of possible reproductive and developmental effects with exposure to DBPs in chlorinated water have also been published (Savitz et al., 1995; Kanitz et al., 1996; Klotz and Pyrch, 1998; Swan et al., 1998; Waller et al., 1998). EPA continues an epidemiology and toxicology research program to this direction and is considering (USEPA, 1997; USEPA, 1998 a,c):

- establishing a Maximum Contaminant Level Goal (MCLG) of zero for $\mathrm{CHCl}_{3}$,

Table 6. Measured concentrations of haloacetonitriles in chlorinated drinking water

\begin{tabular}{ccccc}
\hline & $\mathrm{CHCl}_{2} \mathrm{CN}\left(\mu \mathrm{g} \mathrm{l}^{-1}\right)$ & $\mathrm{CCl}_{3} \mathrm{CN}\left(\mu \mathrm{g} \mathrm{l}^{-1}\right)$ & $\mathrm{CHClBrCN}\left(\mu \mathrm{g} \mathrm{l}^{-1}\right)$ & $\mathrm{CHBr}_{2} \mathrm{CN}\left(\mu \mathrm{g} \mathrm{l}^{-1}\right)$ \\
\hline United States (Krasner et al., 1989) & & & \\
Spring & 1.2 & $<0.012$ & 0.50 & 0.54 \\
Summer & 1.1 & $<0.012$ & 0.58 & 0.48 \\
Fall & 1.1 & $<0.029$ & 0.70 & 0.51 \\
Winter & 1.2 & $<0.029$ & 0.59 & 0.46 \\
Canada (LeBel et al., 1997) & & & \\
Yearly mean & 2.2 & $<0.1$ & 0.2 & $<0.1$ \\
Range & $0.4-5.2$ & $<0.1$ & $<0.1-0.5$ & $<0.1$ \\
\hline
\end{tabular}


Table 7. Measured concentrations of chloropicrin in chlorinated drinking water

\begin{tabular}{cc}
\hline & Chloropicrin $\left(\mu \mathrm{g} \mathrm{l}^{-1}\right)$ \\
\hline United States (Krasner et al., 1989) & 0.16 \\
Spring & 0.12 \\
Summer & 0.10 \\
Fall & 0.10 \\
Winter & 0.3 \\
Canada (LeBel et al., 1997) & $<0.1-0.5$ \\
Yearly mean & \\
Range & $0.10-0.61$ \\
Utah (Nieminski et al., 1993) & \\
Yearly mean & \\
(for 14 water utilities) &
\end{tabular}

Table 8. Measured concentrations of 2,4,6 -trichlorophenol in chlorinated drinking water

\begin{tabular}{lc}
\hline & $2,4,6-$ Trichlorophenol $\left(\mu \mathrm{g} \mathrm{l}^{-1}\right)$ \\
\hline $\begin{array}{c}\text { Utah (Nieminski et al., 1993) } \\
\text { Yearly mean } \\
\text { (range for 14 water utilities) }\end{array}$ & $0.52-1.10$ \\
California (Fu et al., 1994) & 1.96 \\
$\quad \begin{array}{l}\text { Yearly mean } \\
\text { (simulated distribution system) }\end{array}$ & \\
\hline
\end{tabular}

$\mathrm{CHCl}_{2} \mathrm{Br}$ and $\mathrm{CHBr}_{3}$ due to sufficient evidence of carcinogenicity in animals

- establishing a MCLG of $0.06 \mathrm{mg} \mathrm{l}^{-1}$ for $\mathrm{CHClBr}_{2}$, due to liver toxicity and limited evidence of carcinogenicity in animals.

Based on the International Life Sciences Institute panel report in 1997 (ILSI, 1997), EPA is considering changing the MCLG for $\mathrm{CHCl}_{3}$ from zero to $0.3 \mathrm{mg} \mathrm{l}^{-1}$ and leaving the MCLG for dichloroacetic acid at zero, because it is considered as a "likely" cancer hazard to humans (USEPA, 1998a,d). Parametric values for THMs, based on the additional lifetime cancer risk $1 / 1000000$, have also been set by the European Commission in the COM (94) 612 Council Directive, adopted in 1995. The latter derived from revision of the 80/778/EEC Directive about water quality, in which values for THM concentrations in water had not been mentioned. The values set in the revised Directive are 40 and $15 \mu \mathrm{g} \mathrm{l}^{-1}$ for $\mathrm{CHCl}_{3}$ and $\mathrm{CHCl}_{2} \mathrm{Br}$ (Premazzi et al., 1997). In the interests of operating convenience the parametric value for dibromochloromethane can be increased to $25 \mu \mathrm{g} \mathrm{l}^{-1}$ provided that the parametric value for chloroform is reduced to $30 \mu \mathrm{g} \mathrm{t}^{-1}$.
Qualitative target levels for DBPs have been set by the World Health Organization WHO as well, based on the additional cancer risk of $1 / 100000$, and are presented in Table 9.

\section{TECHNOLOGIES FOR DBP CONTROL}

\section{A. Preaursor Removal}

Enhanced coagulation. Total organic carbon concentration and alkalinity of the water affect the effectiveness of this technique. When the alkalinity is low, alum addition may be needed in order to lower the $\mathrm{pH}$ and achieve more effective coagulation of NOM. When alkalinity is high, excessive amount of alum is demanded or an acid (sulfuric) may be needed. The hydrophobic/hydrophilic distribution of TOC plays an important role, since hydrophobic organic carbon is more susceptible to coagulation than hydrophilic organic carbon (Singer and Harrington, 1993).

Granular activated carbon adsorption. It is a relatively expensive process. In most cases a separate postfiltration bed is needed. Empty-bed contact times above $15 \mathrm{~min}$ are required and regeneration frequencies are between three and six months. Decreasing $\mathrm{pH}$ of water or increasing 
alum dosages during pretreatment increase effectiveness of the method (Semmens et al., 1986).

Membrane filtration. It is a relatively expensive process. Nanofilters with membranes having molecular weight cutoffs of 200-500 daltons are needed (Laine et al., 1993).

Powder activated carbon adsorption. Dosage and contact time are the main factors affecting the efficiency of the method. An increase beyond $60 \mathrm{~min}$ in contact time or beyond $30 \mathrm{mg} \mathrm{l}^{-1}$ in dosage is not convenient (Sandrucci et al., 1995).

Use of activated carbon adsorption and membrane filtration, especially when control of pesticide contamination is needed as well, has been reported in the Netherlands (Premazzi et al., 1997). Preozonation on the basis of low doses in order to enhance flocculation is a new technique being developed (Premazzi et al., 1997).

\section{B. Altemative disinfectants}

Monochloramine. It does not produce appreciable amounts of known DBPs, except for DCA and cyanogen chloride (Cowman and Singer, 1994). However, it is a poor primary disinfectant and oxidant and not effective for taste and odor control.

Ozone. It is the most effective oxidant and disinfectant, but since molecular ozone is unstable, a persistent disinfectant residual is not available. Ozone reacts with NOM, forming the following categories of by-products: aldehydes, aldo- and ketoacids, hydrogen peroxide. When bromide is present, brominated DBPs such as bromoform, brominated acetic acids, brominated acetonitriles are formed (Singer, 1994).

Chlorine dioxide. It is an effective oxidant and disinfectant and appropriate for taste and odor control. It does not produce significant concentrations of halogenated DBPs, except for chlorite. However, when chlorine dioxide reacts with NOM, oxidation by-products similar to those formed by ozone are produced (Singer, 1994).

Permanganate. It is an effective oxidant and suitable for taste and odor control, but a poor disinfectant. Additionally, it leads to formation of $\mathrm{MnO}_{2(\mathrm{~s})}$, which is insoluble and creates operational problems at the treatment plant (Singer, 1994).

UV light. It is an effective disinfectant (Wolfe, 1990), but requires low-turbidity water with a low concentration of UV absorbing substances (groundwater or filtered surface water). Residual is not available.
Table 9. Qualitative target levels of DBPs (WHO, 1995)

\begin{tabular}{l|l} 
DBP & Target level $\left(200 \mu \mathrm{g} \mathrm{l}^{-1}\right)$ \\
\hline $2,4,6$ Trichlorophenol & \\
$\mathrm{CHBr}_{3}$ & 100 \\
$\mathrm{CHClBr}_{2}$ & 100 \\
$\mathrm{CHCl}_{2} \mathrm{Br}$ & 60 \\
$\mathrm{CHCl}_{3}$ & 200 \\
DCA & 50 \\
TCA & 100 \\
DCAN & 90 \\
DBAN & 100 \\
TCAN & 1
\end{tabular}

Ozone and chlorine dioxide have been widely used as alternative disinfectants in the United States and in Europe (Richardson et al., 1994; Singer, 1994). The same is true for the use of monochloramine as a preoxidant (USEPA, 1998e).

Combinations of technologies have been considered, such as ozone-monochloramine, hydrogen peroxide-ozone, UV-ozone, UV-hydrogen peroxide, in order to produce highly reactive short-lived free radical species which can oxidize contaminants. It has also been shown (Richardson et al., 1996) that $\mathrm{TiO}_{2} / \mathrm{UV}$ photocatalysis can kill microorganisms and simultaneously lead to degradation of chlorinated organic compounds and DBP precursors. However, this technique does not provide a disinfectant residual. Further research is necessary in order to determine the effectiveness of each technology and the related chemical mechanisms.

\section{DBP removal}

Air stripping. DBPs, which have already been formed, can be removed with the methods of packed column air stripping (packed towers) or diffused air stripping (compressed air). Application of air stripping in Italy has been reported (Premazzi et al., 1997). Air contamination or residual disinfectant removal could be the main negative points of these techniques.

Reverse osmosis. This method can remove 85$90 \%$ of all organic compounds. As membrane technology improves and costs decrease, the procedure seems more attractive for DBP removal (Premazzi et al., 1997).

Granular activated carbon. With this technique many categories of organic compounds can be removed. However, regular maintenance is neces- 
sary and microbiological contamination might take place (Premazzi et al., 1997).

\section{SUMMARY AND CONCLUSIONS}

Chlorination of drinking water leads to the formation of a variety of disinfection by-products that may have adverse health effects on humans. Relative data is still limited, especially for the non-trihalomethane DBPs: haloacetic acids, haloaldehydes, haloketones, haloacetonitriles, chloropicrin and chlorophenols. The objective of minimizing both risks of microbial disease and exposure to DBPs in drinking water is a critical point. In order to solve this problem further research is required, based on chemistry related to DBP formation, their physical and chemical properties and environmental fate. Relative information is given in this review. Reference to actual measurements of DBPs in different countries has been made and proposed changes in regulation of DBPs by EPA and WHO have been presented. Epidemiological and toxicological studies are still continued so that the adverse health effects of DBPs on humans can be specified. Technologies for controlling DBPs in drinking water have also been summarized. Extensive studies of the chemical mechanisms occurring in each case are needed in order to determine the most effective DBP controlling technology or even creating a new one.

\section{SYMBOLS}

$\mathrm{C}_{\mathrm{Br}}$

Bromide ion concentration, $\mathrm{mg} \mathrm{l}^{-1}$ Bromodichloromethane concentra-

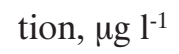

$\mathrm{C}_{\mathrm{CHBr}_{2} \mathrm{Cl}}$ Bromochloromethane concentration, $\mu \mathrm{g} \mathrm{l}^{-1}$

$\mathrm{C}_{\mathrm{CHCl}_{3}} \quad$ Chloroform concentration, $\mu \mathrm{g} \mathrm{^{-1 }}$

$C_{\text {chla }} \quad$ Chlorophyll-a concentration, $\mathrm{mg} \mathrm{m}^{-3}$

$C_{\mathrm{Cl}_{2}} \quad$ Chlorine dose, $\mathrm{mg} \mathrm{l}^{-1}$

$C_{D C A A}$

$C_{\text {Org-N }}$

$C_{T C A A}$

$C_{\text {TTHM }}$

Dichloroacetic acid concentration, $\mu \mathrm{g}^{-1}$ Organic nitrogen concentration, $\mu \mathrm{g} \mathrm{l}^{-1}$

Trichloroacetic acid concentration, $\mu \mathrm{g}^{-1}$

Total trihalomethane concentration, umol $\mathrm{l}^{-1}$

$A c t_{A r-R} \quad$ Activated aromatic content, $\mathrm{mM}(\mathrm{g} \mathrm{C})^{-1}$

DCANFP Dichloroacetonitrile formation potential, $\mu \mathrm{g} \mathrm{l^{-1 }}$

TCAAFP Trichloroacetic acid formation potential, $\mu \mathrm{g}(\mathrm{mg} \text { of } \mathrm{C})^{-1}$

THMFP Trihalomethane formation potential, $\mu \mathrm{g}(\mathrm{mg} \text { of } \mathrm{C})^{-1}$

TOC Total organic carbon concentration, $\mathrm{mg} \mathrm{l}^{-1}$

$U V_{254} \quad$ Ultraviolet radiation absorption at $254 \mathrm{~nm}$ wavelength, $\mathrm{cm}^{-1}$

$t \quad$ Time, h

$T \quad$ Temperature, ${ }^{\circ} \mathrm{C}$

$S$, Sp Summer, Spring (pseudo variables which expresses the season infuence: $\mathrm{S}=1$ for samples collected in summer, $\mathrm{S}=0$ for samples collected during other seasons, $\mathrm{Sp}=1$ for samples collected in spring, $\mathrm{Sp}=0$ for samples collected during the other seasons)

$k_{1} \quad$ Function of $\mathrm{pH}$ (Table 1)

$k_{2} \quad$ Function of temperature (Table 1)

$z \quad$ Function of temperature (Table 1)

\section{REFERENCES}

Babcock, D. B., and Singer, P. C. (1979). Chlorination and coagulation of humic and fulvic acids, J. Am. Water Works Assoc., 71, 149

Bellar, T. A., Lichtenberg, J. J., and Kroner, R. C. (1974). The occurrence of organohalides in chlorinated drinking water, J. Am. Water Works Assoc., 66, 703

Bull, R. J., and Kopfler, F. C. (1991). Health effects of disinfectants and disinfection by-products, American Water Works Association Research Foundation, Denver, Colo.

Bull, R. J., and Robinson, M. (1986). Carcinogenic activity of haloacetonitrile and haloacetone derivatives in the mouse skin and lung, In: Water chlorination: Chemistry, Environmental Impact and Health Effects, Vol. 5, Lewis Publishers, USA, pp 221-227

Cantor, K. P., Lunch, C. F., Hildesheim, M., Dosemeci, M., Lubin, J., Alavan, M., and Craun, G. F. (1998). Drinking water source and chlorination byproducts, I, Risk of bladder cancer, Epidemiology, 9, 21

Christman, R. F., Norwood, D. L., Millington, D. S., Johnson, J. D. and Stevens, A. A. (1983). Identity and yields of major halogenated products of aquatic fulvic acid chlorination, Env. Sci. Tech., 17, 625

Cowman, G. A., and Singer, P. C. (1994). Effect of bromide ion on haloacetic acid speciation resulting from chlorination and chloramination of humic extracts, Proc. Annu. Conf., American Water Works Assoc., Denver, Colo. 
Doyle, T. J., Sheng, W., Cerhan, J. R., Hong, C. P., Sellers, T. A., Kushi, L. H., and Folsom, A. R. (1997). The association of drinking water source and chlorination by-products with cancer incidence among postmenopausal women in Iowa: a prospective cohort study, American Journal of Public Health, 87

Ehrenfeld, J. R. (1986). Controlling volatile emissions in hazardous waste sites, Pollution Technology Review No 126, Noyes Publications, USA, pp 342-380

Engerholm, B. A., and Amy, G. L. (1983). A predictive model for chloroform formation from humic acid, J. AWWA, August 1983

Freedman, M., Cantor, K. P., Lee, N. L., Chen, L. S., Lei, H. H., Ruhl, C. E., and Wang, S. S. (1997). Bladder cancer and drinking water: a population-based case-control study in Washington County, Maryland U. S., Cancer Causes and Control, 8, 738-744

Fu, P., Ruiz, H., Thompson, K., and Spangenberg, C. (1994). Selecting membranes for removing NOM and DBP precursors, J. $A W W A, \mathbf{8 6}$, Dec 1994

Golfinopoulos, S. K., Kostopoulou, M. N., and Lekkas, T. D. (1993). Detection of THMs in the Athens water supply, Proceedings 3rd Conference on Environmental Science and Technology, Vol. B., p 423, Molyvos, Lesvos, Greece

Golfinopoulos, S. K., Kostopoulou, M. N., and Lekkas, T. D. (1996a). Seasonal variation in trihalomethanes level in the water supply system of Athens, 6th International Conference on Environmental Contamination, Delphi, Greece

Golfinopoulos, S. K., Kostopoulou, M. N., and Lekkas, T. D. (1996b). THM formation in the high-bromide water supply of Athens, J. Environ. Sci. Hth., A31, 67-81

Golfinopoulos, S. K., Xylourgidis, N. K., Kostopoulou, M. N. and Lekkas, T. D. (1998). Use of a multiple regression model for predicting trihalomethane formation, Water Research, 32, 2821-2829

Greiner, A. D., Obolensky, A., and Singer, P. C, (1992): Technical Note: Comparing predicted and observed concentrations of DBPs, J. AWWA, Nov 1992

Harrington, G. W., Chowdhurry, Z. K., and Owen, D. M. (1992): Developing a computer model to simulate DBP formation during water treatment, J. Am. Water Works Assoc., 84, 78

Heller-Grossman, L., Manka, J., Limoni-Relis, B., and Rebhun, M. (1993): Formation and distribution of haloacetic acids, THM and TOX in chlorination of bromide-rich lake water, Water Research, 27, 13231331

Hildesheim, M. E., Cantor, K. P., Lynch, C. F., Dosemeci, M., Lubin, J., Alavanja, M., and Craun, G. F. (1998): Drinking water source and chlorination byproducts: risk of colon and rectal cancers, Epidemiology, 9, 29-35

Howard, P. H. (1991a): Handbook of environmental fate and exposure data for organic chemicals, Vol I, Lewis Publishers, USA

Howard, P. H. (1991b): Handbook of environmental fate and exposure data for organic chemicals, Vol II, Lewis Publishers, USA

ILSI (1997): An evaluation of EPA's proposed guidelines for carcinogen risk assessment using chloroform and dichloroacetate as case studies: report of an expert panel, International Life Sciences Institute, Health and Environmental Sciences Institute

King, W. D., and Marrett, L. D. (1996): Case-control study of water source and bladder cancer, Cancer Causes and Control, 7, 596-604

Klotz, J. B., and Pyrch, L. A. (1998): A case-control study of neural tube defects and drinking water contaminants, New Jersey Department of Health and Senior Services

Krasner, S. W., McGuire, M. J., Jacangelo, J. J. et al., (1989): The occurrence of disinfection by-products in U.S. drinking water, J. Am. Water Works Assoc., 81, 41

Laine, J. M., Jacangelo, J. G., Cummings, E. W., Carns, K. E., and Malleviale, J., (1993): Influence of bromide on low-pressure membrane filtration for controlling DBPs in surface waters, J. AWWA, 85, 87

LeBel, G. L., Benoit, F. M., Williams, D. T. (1997): A one-year survey of halogenated DBPs in the distribution system of treatment plants using three different disinfection processes, Chemosphere, 34, 2301-2317

Lekkas, T.D., (1996): Environmental Engineering I: Management of Water Resources, Univerity of the Aegean, Department of Environmental Studies, Mytilene, Greece

Lyde, D. R. (1993-94): Handbook of chemistry and physics, 74th edition

Mackay, D., Ying Shiu, V., and Ching Ma, K. (1992a): Illustrated handbook of physical-chemical properties and 
environmental fate for organic chemicals, Vol. I, Lewis Publishers, USA

Mackay, D., Ying Shiu, V., and Ching Ma, K. (1992b): Illustrated handbook of physical-chemical properties and environmental fate for organic chemicals, Vol. III, Lewis Publishers, USA

Malcolm Pirnie Inc. (1992): Water Treatment Plant Simulation Program, Version 1.21, User's manual, U. S. Environmental Protection Agency (EPA), Washington, D.C.

Merck. (1989): The Merck Index: An encyclopedia of chemicals, drugs, and biologicals, 11th Edition, Merck \& Co. Inc., USA

Miller, J. W., and Uden, P. C. (1983): Characterization of non-volatile aqueous chlorination products of humic substances, Envir. Sci. Technol., 17, 150

Nieminski, E. C., Chaudhuri, S., and Lamoreaux, T. (1993): The occurrence of DBPs in Utah drinking waters, $J$. $A W W A$, Vol. 85, Sep 1993

Oliver, B. G. (1983). Dihaloacetonitriles in drinking water: algae and fulvic acid as precursors, Env. Sci. Tech., 17

Pereira, M. A., Daniel, F. B., and Lin, E. L. C. (1986): Relationship between metabolism of haloacetonitriles and chloroform and their carcinogenic activity, In: Water Chlorination: Chemistry, Environmental Impact and Health Effects, Vol. 5, Lewis Publishers, USA, pp 229-236

Peters, R. J. B., Erkelens, C., De Leer, E. W. B., and De Galan, L. (1991): The analysis of halogenated acids in Dutch drinking water, Water Research, 25, 473-477

Pourmoghaddas, H., and Stevens, A. A. (1995): Relationship between trihalomethanes and haloacetic acids with total organic halogen during chlorination, Water Research, 29, 2059-2062

Premazzi, G., Cardoso, C., Conio, O., Palumbo, F., Ziglio, G., Meucci, L., Borgioli, A. (1997): Standards and strategies in the European Union to control trihalomethanes in drinking water, Environment Institute, European Commission Joint Research Centre and Techware, Italy

Quimby, B. D., Delaney, M. F., Uden, P. C., and Barnes, R. M. (1980): Determination of the aqueous chlorination products of humic substances by gas chromatography with microwave emission detection, Anal. Chem., 52, 259

Reckow, D. A., Singer, P. C., and Malcolm, R. L. (1990): Chlorination of humic materials: by-product formation and chemical interpretations, Envir. Sci. Technol., 24, 1655

Reckow, D. A., and Singer, P. C. (1984): The removal of organic halide precursors by preozonation and alum coagulation, J. Am. Water Works Assoc., 76, 151

Regli, S., Cromwell, J. E., Zhang, X., Gelderloos, A. B., Grubbs, W. D., Letkiewicz, F., and Machler, B. A. (1992): Framework for decision-making: an EPA perspective, Rep. No. EPA 811-R-92-005, U.S. Environmental Protection Agency (EPA), Washington, D.C.

Richardson, S. D., Thruston, A. D., Collette, T. W., Patterson, K. S., Lykins, B. W., and Ireland, J. C. (1996): Identification of $\mathrm{TiO}_{2} / \mathrm{UV}$ disinfection byproducts in drinking water, Env. Sci. Tech., 30, 3327-3334

Rook, J. J. (1974): Formation of haloforms during chlorination of natural waters, Water Treat. Exam., 23, 234

Sandrucci, P., Merlo, G., and Meucci, L. (1995): PAC activity vs by-product precursors in water disinfection, Water Research, 29, 2299-2308

Savitz, D. A., Andrews, K. W., and Pastore, R. M. (1995): Drinking water and pregnancy outcome in central North Carolina: source, amount and trihalomethane levels, Environ. Health Perspectives, 103, 592-596

Semmens, M. J., and Staples, A. B. (1986): The nature of organics removed during treatment of Mississippi River water, J. $A W W A, \mathbf{7 8 ,} 86$

Shiu W. (1994): Chlorophenols and alkylphenols: a review and correlation of environmentally relevant properties and fate in an evaluative environment, Chemosphere, 29, 1155-1224

Simmon, V., F., Kauhanen, K., and Tardiff, R. G. (1977): Dev. Toxicol. Environ. Sci., 2, 249

Singer, P. C., and Harrington, G. W. (1993): Coagulation of DBP precursors: theoretical and practical considerations, Proc. Water Quality Technol. Conf., American Water Works Assoc., Denver, Colo., 1-19

Singer, P. C. (1993): Formation and characterization of disinfection by-products, Safety of water disinfection: balancing microbial risks, G. F., Craun ed., Int. Life Sciences Inst. Press, Washington, D. C., 201-219

Singer, P. C. (1994): Control of disinfection by-products in drinking water, J. Env. Eng., 120, Jul/Aug 1994

Sittig, M. (1985): Handbook of toxic and hazardous chemicals and carcinogens, 2nd ed, Noyes Publications, USA

Stevens, A. A., Slocum, C. J., Seeger, D. P., and Robeck, G. G. (1976): Chlorination of organics in drinking water, J. Am. Water Works Assoc., 68, 615

Swan, S. W., Waller, K., Hopkins, B., Windham, G., Fenster, L., and Schaefer Neutra, R. (1998): A prospective 
study of spontaneous abortion: relation to amount and source of drinking water consumed in early pregnancy, Epidemiology, 9, 126-133

Trehy, M. L., and Bieber, T. I. (1980): Proceedings of the ACDS Division of Environmental Chemistry, San Fransisco, CA, Aug 24-29, American Chemical Society: Washington, D.C.

U.S. EPA (1979): National Interim Primary Drinking Water Regulations; Control of trihalomethanes in drinking water, Vol. 44, No 231, pp 68624-68707

U.S. EPA (1997): Summaries of new health effects data, Office of Science and Technology, Office of Water

U.S. EPA (1998a): National Primary Drinking Water Regulations: Disinfectants and Disinfection By-Products Notice of Data Availability, Office of Ground Water and Drinking Water, http://www.epa.gov/OGWDW/m dbp/dis.html

U.S. EPA (1998b): Quantification of cancer risk from exposure to chlorinated water, Office of Science and Technology, Office of Water

U.S. EPA (1998c): Health risk assessment/characterization of the drinking water disinfection byproduct chloroform, Office of Science and Technology, Office of Water

U.S. EPA (1998d): Dichloroacetic acid: carcinogenicity identification characterization summary, National Center for Environmental Assessment-Washington Office, Office of Research and Development

U.S. EPA (1998e): Disinfecting drinking water with chloramine, http://www.epa.gov/region09/water/chloramine.html

Vena, J. E., Graham, S., Freudenheim, J. O., Marshall, J., Sielezny, M., Swanson, M., and Sufrin, G. (1993): Drinking water, fluid intake, and bladder cancer in western New York, Archives of Environmental Health, 48

Vogel (1989): Vogel's Textbook of Practical Organic Chemistry, 5th edition, John Wiley \& Sons Inc., New York

Waller, K., Swan, S. H., DeLorenze, G., and Hopkins, B. (1998): Trihalomethanes in drinking water and spontaneous abortion, Epidemiology, 9, 134-140

WHO (1995): Desinfection de l' eau, Local authorities, health and environment briefing pamphlet series, No 3

Williams, D. T., LeBel, G. L., and Benoit, F. M. (1997): Disinfection by-products in Canadian drinking water, Chemosphere, 34, 299-316

Wolfe, R. L. (1990): Ultraviolet disinfection of potable water, Env. Sci. Tech., 24, 768 
Annex I. Physical - chemical properties and environmental fate of Disinfection By-Products

\begin{tabular}{|c|c|c|c|c|c|c|c|c|}
\hline Compound & $M W$ & $\begin{array}{l}\text { Physical } \\
\text { characteristics } \\
\text { (C) }\end{array}$ & $\begin{array}{l}\text { Boiling } \\
\text { point } \\
\text { (̈C) }\end{array}$ & $\begin{array}{l}\text { Melting } \\
\text { point }\end{array}$ & Saluble in & W ater Solubility & Vapor Pressure & $\begin{array}{l}\text { Reactions in } \\
\text { water }\end{array}$ \\
\hline Chloroform & 119.39 & $\begin{array}{l}\text { Clear, colorless } \\
\text { liquid with a } \\
\text { characteristic odor }\end{array}$ & 61.7 & -63.5 & $\begin{array}{l}\text { Organic } \\
\text { solvents }\end{array}$ & $\begin{array}{l}7950 \mathrm{mg} \mathrm{l}^{-1} \\
\text { at } 25^{\circ} \mathrm{C}\end{array}$ & $\begin{array}{l}246 \mathrm{~mm} \mathrm{Hg} \text { at } \\
25^{\circ} \mathrm{C}\end{array}$ & $\begin{array}{l}\text { Evaporation } \\
\text { Biodegradation }\end{array}$ \\
\hline $\begin{array}{l}\text { Dichlorobro- } \\
\text { momethane }\end{array}$ & 163.83 & Liquid & 90 & -57.1 & $\begin{array}{l}\text { Organic } \\
\text { solvents }\end{array}$ & $\begin{array}{l}4700 \mathrm{mg} \mathrm{l}^{-1} \\
\text { at } 25^{\circ} \mathrm{C}\end{array}$ & $\begin{array}{l}50 \mathrm{~mm} \mathrm{Hg} \text { at } \\
25^{\circ} \mathrm{C} \\
\text { biodegradation }\end{array}$ & $\begin{array}{l}\text { Evaporation } \\
\text { Anaerobic }\end{array}$ \\
\hline $\begin{array}{l}\text { Dibromo- } \\
\text { chloromethane }\end{array}$ & 208.28 & $\begin{array}{l}\text { Clear, colorless } \\
\text { liquid }\end{array}$ & 119-120 & -20 & $\begin{array}{l}\text { Organic } \\
\text { solvents }\end{array}$ & $\begin{array}{l}4400 \mathrm{~m} \mathrm{l}^{-1} \\
\text { at } 25^{\circ} \mathrm{C}\end{array}$ & $\begin{array}{l}15 \mathrm{~mm} \mathrm{Hg} \text { at } \\
10.5^{\circ} \mathrm{C} \\
\text { biodegradation }\end{array}$ & $\begin{array}{l}\text { Evaporation } \\
\text { Anaerobic }\end{array}$ \\
\hline Bromoform & 252.77 & $\begin{array}{l}\text { Colorless - yellow } \\
\text { liquid with } \\
\text { chlorofomlike odor }\end{array}$ & 149.5 & 7.70 & $\begin{array}{l}\text { Organic } \\
\text { solvents }\end{array}$ & $\begin{array}{l}3974 \mathrm{mg} \mathrm{l}^{-1} \\
\text { at } 20^{\circ} \mathrm{C}\end{array}$ & $\begin{array}{l}7.36 \mathrm{~mm} \mathrm{Hg} \\
\text { at } 25^{\circ} \mathrm{C}\end{array}$ & $\begin{array}{l}\text { Evaporation } \\
\text { Biodegradation }\end{array}$ \\
\hline $\begin{array}{l}\text { Monochloro- } \\
\text { acetic acid } \\
\text { (MCA) }\end{array}$ & 94.50 & $\begin{array}{l}\text { Colorless - white } \\
\text { crystalline solid }\end{array}$ & $\begin{array}{l}188 \text { for } \alpha-\text {, } \\
187.9 \text { for } \\
\beta \text { - and } \\
187.8 \text { for } \\
\gamma \text { - isomer } \\
\end{array}$ & $\begin{array}{l}63 \text { for } \alpha-\text {, } \\
56.2 \text { for } \beta \text { - } \\
\text { and } 52.5 \\
\text { for } \gamma- \\
\text { isomer }\end{array}$ & $\begin{array}{l}\text { Water } \\
\text { Ether } \\
\text { Benzene } \\
\text { Alcohols }\end{array}$ & $\begin{array}{l}1.09 \times 106 \mathrm{mg} \mathrm{l}^{-1} \\
\text { at } 25^{\circ} \mathrm{C}\end{array}$ & - & - \\
\hline $\begin{array}{l}\text { Dichloroacetic } \\
\text { acid (DCA) }\end{array}$ & 128.94 & $\begin{array}{l}\text { Liquid with } \\
\text { pungent odor }\end{array}$ & 194 & 13.5 & $\begin{array}{l}\text { Water } \\
\text { Acetone } \\
\text { Ether } \\
\text { Alcohols } \\
\end{array}$ & Miscible & - & - \\
\hline $\begin{array}{l}\text { Trichloroacetic } \\
\text { acid (TCA) }\end{array}$ & 163.39 & $\begin{array}{l}\text { Colorless, } \\
\text { crystalline solid } \\
\text { with characteristic } \\
\text { odor, very corrosive }\end{array}$ & 197.5 & $\begin{array}{l}58 \text { for } \alpha- \\
\text { and } 49.6 \\
\text { for } \beta \text { - } \\
\text { isomer }\end{array}$ & $\begin{array}{l}\text { Ether } \\
\text { Alcohols }\end{array}$ & $\begin{array}{l}1.50 \times 106 \mathrm{mg} \mathrm{l}^{-1} \\
\text { at } 25^{\circ} \mathrm{C}\end{array}$ & - & - \\
\hline $\begin{array}{l}\text { Monobromo- } \\
\text { acetic acid } \\
(\mathrm{MBA})\end{array}$ & 138.95 & - & 208 & 50 & \begin{tabular}{|l|} 
Water \\
Alcohols \\
Ethers \\
Acetone \\
Benzene \\
\end{tabular} & $\begin{array}{l}1.75 \times 106 \mathrm{mg} \mathrm{l}^{-1} \\
\text { at } 25^{\circ} \mathrm{C}\end{array}$ & - & - \\
\hline $\begin{array}{l}\text { Dibromoacetic } \\
\text { acid (DBA) }\end{array}$ & 217.84 & Crystalline solid & 195 & 48 & $\begin{array}{l}\text { Water } \\
\text { Ether } \\
\text { Alcohols } \\
\end{array}$ & $\begin{array}{l}2.11 \times 106 \mathrm{mg} \mathrm{l}^{-1} \\
\text { at } 25^{\circ} \mathrm{C}\end{array}$ & - & - \\
\hline $\begin{array}{l}\text { Tribromoacetic } \\
\text { acid (TBA) }\end{array}$ & 296.78 & Crystalline solid & 245 & 135 & $\begin{array}{l}\text { Water } \\
\text { Ether } \\
\text { Alcohols }\end{array}$ & $\begin{array}{l}2.00 \times 106 \mathrm{mg} \mathrm{l}^{-1} \\
\text { at } 25^{\circ} \mathrm{C}\end{array}$ & - & - \\
\hline $\begin{array}{l}\text { Bromochloro- } \\
\text { acetic acid } \\
\text { (BCA) }\end{array}$ & 173.39 & - & 103-104 & 38 & $\begin{array}{l}\text { Water } \\
\text { Ether } \\
\text { Acetone } \\
\text { Alcohols } \\
\end{array}$ & - & - & - \\
\hline $\begin{array}{l}\text { Monochloro- } \\
\text { acetonitrile }\end{array}$ & 75.50 & - & 126-127 & - & $\begin{array}{l}\text { Ether } \\
\text { Alcohols } \\
\end{array}$ & - & - & - \\
\hline $\begin{array}{l}\text { Dichloro- } \\
\text { acetonitrile }\end{array}$ & 109.94 & - & $112-113$ & - & Alcohols & - & - & - \\
\hline $\begin{array}{l}\text { Bromoaceto- } \\
\text { nitrile }\end{array}$ & 119.95 & Pale yellow color & $150-151$ & - & Ether & - & - & - \\
\hline $\begin{array}{l}\text { Trichloro- } \\
\text { acetonitrile }\end{array}$ & 144.39 & Liquid & 84.6 & -42 & - & - & - & - \\
\hline $\begin{array}{l}1,1 \text { - Dichloro- } \\
\text { acetone }\end{array}$ & 126.98 & Oily liquid & 120 & - & Acetone & Very low & - & - \\
\hline $\begin{array}{l}1,3 \text { - Dichloro- } \\
\text { acetone }\end{array}$ & 126.98 & - & 173 & 45 & $\begin{array}{l}\text { Water } \\
\text { Ether } \\
\text { Alcohols }\end{array}$ & - & - & - \\
\hline $\begin{array}{l}\text { Chloro- } \\
\text { acetaldehyde }\end{array}$ & 78.5 & $\begin{array}{l}\text { Clear, colorless } \\
\text { liquid with pungent } \\
\text { odor }\end{array}$ & 142-144 & 87 & Ethers & $\begin{array}{l}7 \times 106 \mathrm{mg} \mathrm{l}^{-1} \\
\text { at } 25^{\circ} \mathrm{C}\end{array}$ & $\begin{array}{l}317 \mathrm{~mm} \mathrm{Hg} \\
\text { at } 25^{\circ} \mathrm{C}\end{array}$ & - \\
\hline $\begin{array}{l}\text { Dichloro- } \\
\text { acetaldehyde }\end{array}$ & 112.94 & - & 90-91 & - & Alcohols & - & - & - \\
\hline
\end{tabular}


Annex I. Physical - chemical properties and environmental fate of Disinfection By-Products (continued)

\begin{tabular}{|c|c|c|c|c|c|c|c|c|}
\hline Compound & $M W$ & $\begin{array}{l}\text { Physical } \\
\text { characteristics } \\
\text { (C) }\end{array}$ & $\begin{array}{l}\text { Boiling } \\
\text { point } \\
\text { (C) }\end{array}$ & $\begin{array}{l}\text { Melting } \\
\text { poirt }\end{array}$ & Soluble in & W ater Solubility & Vapor Pressure & $\begin{array}{l}\text { Peactions in } \\
\text { water }\end{array}$ \\
\hline $\begin{array}{l}\text { Trichloro- } \\
\text { acetaldehyde }\end{array}$ & 147.40 & $\begin{array}{l}\text { Oily liquid with } \\
\text { pungent, irritating } \\
\text { odor }\end{array}$ & - & $129-135$ & \begin{tabular}{|l|} 
Water \\
Ether \\
Alcohols
\end{tabular} & - & - & - \\
\hline $\begin{array}{l}\text { Tribromo- } \\
\text { acetaldehyde }\end{array}$ & 280.78 & $\begin{array}{l}\text { Yellowish, oily } \\
\text { liquid }\end{array}$ & 174 & - & \begin{tabular}{|l|} 
Water \\
Ether \\
Alcohols
\end{tabular} & - & - & - \\
\hline Chloral hydrate & 165.42 & $\begin{array}{l}\text { Pungent odor, } \\
\text { caustic taste }\end{array}$ & 98 & 57 & Acetone & - & - & - \\
\hline Chloropicrin & 164.5 & \begin{tabular}{|l} 
Colorless, oily \\
liquid, with pungent \\
odor, causes tears
\end{tabular} & 112 & -69.2 & \begin{tabular}{|l|} 
Ether \\
Benzene \\
Alcohols
\end{tabular} & $\begin{array}{l}1621 \mathrm{mg} \mathrm{l}^{-1} \\
\text { at } 25^{\circ} \mathrm{C}\end{array}$ & $\begin{array}{l}23.8 \mathrm{~mm} \mathrm{Hg} \\
\text { at } 25^{\circ} \mathrm{C}\end{array}$ & - \\
\hline $\begin{array}{l}2 \text { - Chloro- } \\
\text { phenol }\end{array}$ & 128.56 & Liquid & $175-176$ & 9 & \begin{tabular}{|l|} 
Ether \\
Benzene \\
Alcohols
\end{tabular} & $\begin{array}{l}28000 \mathrm{mg} \mathrm{l}^{-1} \\
\text { at } 25^{\circ} \mathrm{C}\end{array}$ & $\begin{array}{l}1.42 \mathrm{~mm} \mathrm{Hg} \text { at } \\
25^{\circ} \mathrm{C}\end{array}$ & $\begin{array}{l}\text { Adsorption on } \\
\text { sediments } \\
\text { Photolysis } \\
\text { Biodegradation }\end{array}$ \\
\hline $\begin{array}{l}3 \text { - Chloro- } \\
\text { phenol }\end{array}$ & 128.56 & - & 214 & 33 & $\begin{array}{l}\text { Ether } \\
\text { Benzene } \\
\text { Alcohols }\end{array}$ & $\begin{array}{l}26000 \mathrm{mg} \mathrm{l}^{-1} \\
\text { at } 25^{\circ} \mathrm{C}\end{array}$ & $\begin{array}{l}0.119 \mathrm{~mm} \mathrm{Hg} \text { at } \\
25^{\circ} \mathrm{C}\end{array}$ & $\begin{array}{l}\text { Biodegradation } \\
\text { Photolysis } \\
\text { Adsorption on } \\
\text { sediments } \\
\text { Evaporation }\end{array}$ \\
\hline $\begin{array}{l}4 \text { - Chloro- } \\
\text { phenol }\end{array}$ & 128.56 & - & 220 & 43 & \begin{tabular}{|l|} 
Ether \\
Benzene \\
Alcohols
\end{tabular} & $\begin{array}{l}27000 \mathrm{mg} \mathrm{l}^{-1} \\
\text { at } 25^{\circ} \mathrm{C}\end{array}$ & $\begin{array}{l}0.087 \mathrm{~mm} \mathrm{Hg} \text { at } \\
25^{\circ} \mathrm{C}\end{array}$ & $\begin{array}{l}\text { Adsorption on } \\
\text { sediments } \\
\text { Photolysis } \\
\text { Biodegradation }\end{array}$ \\
\hline $\begin{array}{l}\text { 2,3 - Dichloro- } \\
\text { phenol }\end{array}$ & 163.00 & - & - & $57-59$ & \begin{tabular}{|l|} 
Ether \\
Alcohols
\end{tabular} & - & - & - \\
\hline $\begin{array}{l}2,4 \text { - Dichloro- } \\
\text { phenol }\end{array}$ & 163.00 & \begin{tabular}{|l|} 
Colorless, \\
crystalline solid
\end{tabular} & 210 & 45 & \begin{tabular}{|l|} 
Ether \\
Benzene \\
Alcohols
\end{tabular} & $\begin{array}{l}4500 \mathrm{mg} \mathrm{l}^{-1} \\
\text { at } 25^{\circ} \mathrm{C}\end{array}$ & $\begin{array}{l}0.118 \mathrm{~mm} \mathrm{Hg} \\
\text { at } 25^{\circ} \mathrm{C}\end{array}$ & - \\
\hline $\begin{array}{l}\text { 2,5 - Dichloro- } \\
\text { phenol }\end{array}$ & 163.00 & - & 211 & 59 & \begin{tabular}{|l|} 
Ether \\
Benzene \\
Alcohols
\end{tabular} & - & - & - \\
\hline $\begin{array}{l}\text { 2,6 - Dichloro- } \\
\text { phenol }\end{array}$ & 163.00 & \begin{tabular}{|l|} 
White, \\
crystalline solid
\end{tabular} & $219-220$ & $68-69$ & \begin{tabular}{|l|} 
Ether \\
Benzene \\
Alcohols
\end{tabular} & $\begin{array}{l}172 \mathrm{mg} \mathrm{l}^{-1} \\
\text { at } 25^{\circ} \mathrm{C}\end{array}$ & $\begin{array}{l}0.0165 \mathrm{~mm} \mathrm{Hg} \\
\text { at } 25^{\circ} \mathrm{C}\end{array}$ & - \\
\hline $\begin{array}{l}\text { 3,4 - Dichloro- } \\
\text { phenol }\end{array}$ & 163.00 & - & 253.5 & 68 & \begin{tabular}{|l|} 
Ether \\
Benzene \\
Alcohols
\end{tabular} & - & - & - \\
\hline $\begin{array}{l}\text { 3,5 - Dichloro- } \\
\text { phenol }\end{array}$ & 163.00 & - & 233 & 68 & \begin{tabular}{|l|} 
Ether \\
Alcohols
\end{tabular} & - & - & - \\
\hline $\begin{array}{l}\text { 2,3,4 - Trichlo- } \\
\text { rophenol }\end{array}$ & 197.45 & Liquid & - & 83.5 & \begin{tabular}{|l} 
Ether \\
Benzene \\
Alcohols
\end{tabular} & - & - & - \\
\hline $\begin{array}{l}\text { 2,3,5 - Trichlo- } \\
\text { rophenol }\end{array}$ & 197.45 & - & $248-249$ & 62 & \begin{tabular}{|l} 
Ether \\
Alcohols
\end{tabular} & - & - & - \\
\hline $\begin{array}{l}2,3,6 \text { - Trichlo- } \\
\text { rophenol }\end{array}$ & 197.45 & - & - & 58 & \begin{tabular}{|l|} 
Ether \\
Benzene \\
Alcohols \\
\end{tabular} & - & - & - \\
\hline $\begin{array}{l}2,4,5 \text { - Trichlo- } \\
\text { rophenol }\end{array}$ & 197.45 & $\begin{array}{l}\text { Strong phenolic } \\
\text { odor }\end{array}$ & 253 & 57 & Alcohols & $\begin{array}{l}982 \mathrm{mg} \mathrm{l}^{-1} \text { at } \\
25^{\circ} \mathrm{C}\end{array}$ & $\begin{array}{l}0.0496 \mathrm{~mm} \mathrm{Hg} \\
\text { at } 25^{\circ} \mathrm{C}\end{array}$ & $\begin{array}{l}\text { Photolysis } \\
\text { Adsorption on } \\
\text { suspended solids } \\
\text { and sediments }\end{array}$ \\
\hline $\begin{array}{l}2,4,6 \text { - Trichlo- } \\
\text { rophenol }\end{array}$ & 197.45 & $\begin{array}{l}\text { Strong phenolic } \\
\text { odor }\end{array}$ & 246 & 69 & \begin{tabular}{|l} 
Ether \\
Alcohols
\end{tabular} & $\begin{array}{l}800 \mathrm{mg} \mathrm{l}^{-1} \text { at } \\
25^{\circ} \mathrm{C}\end{array}$ & $\begin{array}{l}0.0149 \mathrm{~mm} \mathrm{Hg} \\
\text { at } 25^{\circ} \mathrm{C}\end{array}$ & $\begin{array}{l}\text { Photolysis } \\
\text { Biodegradation } \\
\text { Adsorption on } \\
\text { sediments } \\
\text { Evaporation }\end{array}$ \\
\hline $\begin{array}{l}\text { 3,4,5 - Trichlo- } \\
\text { rophenol }\end{array}$ & 197.45 & - & 271-277 & 101 & Ether & - & - & - \\
\hline
\end{tabular}

